\author{
Asian Journal of \\ Medical and Biological Research \\ ISSN 2411-4472 (Print) 2412-5571 (Online) \\ www.ebupress.com/journal/ajmbr
}

\title{
Article \\ Effect of supplementation of vitamin $E$ and selenium from Lolyvit-ES on the performance of broiler
}

\author{
Mohammad Salahuddin $^{1 *}$, Zahirul Haque Khandaker ${ }^{2}$, Mohammad Mohiuddin $^{2}$ and Md. Mostain Billah ${ }^{3}$ \\ ${ }^{1}$ Bangladesh Milk Producer's Cooperative Union Limited \\ ${ }^{2}$ Department of Animal Nutrition, Bangladesh Agricultural University, Mymensingh 2202, Bangladesh \\ ${ }^{3}$ Bangladesh Livestock Research Institute, Regional Station, Shahjadpur, Sirajgonj, Bangladesh
}

*Corresponding author: Mohammad Salahuddin, Bangladesh Milk Producer's Cooperative Union Limited. Email: salahuddin_mvita@yahoo.com

Received: 07 December 2017/Accepted: 27 December 2017/ Published: 28 December 2017

\begin{abstract}
An experiment was conducted in the poultry rearing unit of Sahjalal Animal Nutrition Field Laboratory, Bangladesh Agricultural University, Mymensingh for a period of 30 days by using 108 one week aged straight run Starbro broiler chicks to find out the effect of vitamin E and selenium as feed supplement for the performance of broiler. Chicks were distributed into 4 dietary treatment groups each having three replications $\left(R 1, R_{2}, R_{3}\right)$ and each replication contains 9 chicks. Dietary treatment groups were $T_{0}($ Control i.e. without supplemental vitamin $\mathrm{E}$ and Selenium), $\mathrm{T}_{1}$ (Control $+50 \mathrm{mg}$ vitamin $\mathrm{E} 0.11 \mathrm{mg}$ selenium per $\mathrm{kg}$ diet), $\mathrm{T}_{2}$ (Control $+100 \mathrm{mg}$ vitamin and $0.22 \mathrm{mg}$ Selenium per $\mathrm{kg}$ diet and $\mathrm{T}_{3}$ (Control $+150 \mathrm{mg}$ vitamin $\mathrm{E}$ and 0.33 $\mathrm{mg}$ Selenium per kg diet). At end of the feeding trail the body weight of birds were 1238.28, 1231.85, 1272.59, and $1218.33 \mathrm{gm} /$ bird in treatment groups $\mathrm{T}_{0}, \mathrm{~T}_{1}, \mathrm{~T}_{2}$ and $\mathrm{T}_{3}$ respectively which differ significantly $(\mathrm{p}<0.05)$ where highest body weight observed in $\mathrm{T}_{2}$ group . Body weight gain was highest in $\mathrm{T}_{2}$ (control+100mg vitamin $\mathrm{E}$ and $0.22 \mathrm{mg}$ Selenium per $\mathrm{kg}$ diet) and lowest in $\mathrm{T}_{0}$ (control). Total Feed consumption during the experimental period was 2480.30, 2523.80, 2564.56 and $2555.39 \mathrm{~g}$ for $\mathrm{T}_{0}, \mathrm{~T}_{1}, \mathrm{~T}_{2}$ and $\mathrm{T}_{3}$ respectively. At $2^{\text {nd }}$ and $3^{\text {rd }}$ week of age, weekly feed conversion ratio were significantly $(\mathrm{p}<0.05)$ higher in $\mathrm{T}_{2}$ group than the other groups including control. Meat yield parameter of broilers showed significant $(\mathrm{P}<0.05)$ differences in dressing weight, breast weight and shank weight. Based on the above findings, the result suggest that supplementation of Vitamin E $100 \mathrm{mg}$ and $0.22 \mathrm{mg}$ Selenium per $\mathrm{kg}$ diet from "Lolyvit-ES" as a source of Vitamin E and Selenium may be used in broiler rations.
\end{abstract}

Keywords: broiler; vitamin; selenium; supplementation; performance

\section{Introduction}

Broiler industry is playing an important role in agricultural economy of Bangladesh. It provides a large part of increasing demand for animal protein, cash income and employment opportunities. Poultry meat and eggs contribute approximately $37 \%$ of total animal protein in the country (Ahmed and Islam, 1990). There is a great possibility of growth and expansion of this sector both at domestic and commercial level. This is justified by the fact that farmers of this country are becoming more interested in broiler farming from the last two decades.

Vitamin and mineral plays an important role in efficient production of broiler. Among them Vitamin $\mathrm{E}$ and Selenium have an important relationship. Vitamin E has been shown to be essential to integrity and optimum function of the reproductive, muscular, circulatory, nervous and immune system (Sheffy and Williams, 1981; Mc Dowell et al., 1996). It is well established that some functions of vitamin E, however, can be fulfilled in part or entirely by traces of selenium or by certain synthetic antioxidants. In poultry nutrition Selenium acts as nonspecific antioxidant, protects against per oxidation in tissues and membranes, participates in the biosynthesis of obiquinine, participates in hydrogen transport along the respiratory chain, prevents degeneration and fibrosis of 
the pancreas in chicks, influences the absorption and retention of Vitamin E. Vitamin E and Selenium recognized as an essential nutrient for poultry. Both Vitamin E and Selenium are needed for adequate immune response by poultry (NRC, 1983).

Both vitamin E and Selenium protect leukocytes and macrophages during phagocytosis the mechanism whereby mammals immunologically kill invading bacteria. Vitamin E and Selenium may help these cells to survive the toxic products that are produced to effectively kill ingested bacteria (Badwey and Karnovsky,1980; Leassard et al., 1991).Vitamin E requirement of broiler chicks recommended by National Research Council (NRC-1994) is $10 \mathrm{IU} / \mathrm{kg}$ of diet, but Combs and Scott (1977) reported that at least $30 \mathrm{IU} / \mathrm{kg}$ diet was needed to minimize susceptibility of hepatic microbes to per oxidation and Selenium requirement for broiler chick recommended by NRC-1994, $0.15 \mathrm{mg} / \mathrm{kg}$ diet. Ullery (1974) reported that Selenium concentration in grain is highly variable $(0.40$ to $0.05 \mathrm{ppm}$ ). Many of the Vitamins are oxidized with coming into contact with oxygen. So birds cannot fill up their requirement from natural diet.

Because of the high variability and unknown bio availability vitamin and mineral in feeds, poultry producers have come to rely to large extent on commercially synthesized vitamins. In practice, feed manufactures usually ignore to a certain degree the contribution of many vitamins in feed stuffs and provide complete vitamin supplementation.

At present various synthetic vitamin E and Selenium premix are available in the market and their indiscriminate practice in broiler industry may follow without much scientific consideration. "Loly vit-ES" is one of the commercial vitamin E and Selenium premix, which is produced and marketed by Loly Pharma Ltd., Bangladesh. The manufacturers of this product claim that it exert its beneficial effects on the performance of broilers based on common principles of vitamin E and Selenium. Experimental results on the effect of Vitamin $\mathrm{E}$ and Selenium in the diet of broiler chicks are not available in the local condition.

Since vitamin E and Selenium appeared as a performance enhancer in broiler in the market. It would be interesting to conduct an experiment with this product to investigate its beneficial effects. Therefore the present study was undertaken to know the effects of supplementation of "Lolyvit-ES" as a source of vitamin E and Selenium on broiler performance (Growth rate, feed consumption, feed efficiency, meat characteristics and dressing percentage).

\section{Materials and Methods}

The experiment was conducted in the poultry rearing unit of Sahjalal Animal Nutrition Field Laboratory, Bangladesh Agricultural University, Mymensingh for a period of 30 days by using 108 one week aged straight run starbro broiler chicks to find out the effect of vitamin $\mathrm{E}$ and selenium as feed supplement for the performance of broiler.

\subsection{Experimental birds}

One hundred and eight straight run day old starbro broiler chicks were collected from BRAC hatchery, Valuka, Mymensingh. The chicks were brooded on deep litter upto 7 days.

\subsection{Chemical composition of Lolyvit-ES}

The Lolyvit-ES is vitamin E - mineral premix manufactured by Loly Pharma Ltd., Bangladesh. Lolyvit- ES contain 10 gm Vitamin E and 50 gm Selenium.

\subsection{Dietary treatments}

After 7 days chicks were weighted and randomly distributed into 4 dietary treatment groups namely $\mathrm{T}_{0}, \mathrm{~T}_{1}, \mathrm{~T}_{2}$, and $T_{3}$ and each having three replications $\left(R_{1}, R_{2}, R_{3}\right)$ and each replication contains 9 chicks. The basal diet (considered as control) contained $15.35 \mathrm{mg}$ vitamin $\mathrm{E}$ and $0.36 \mathrm{mg}$ selenium. Dietary treatment groups were -

$\mathrm{T}_{0}$ (Control i.e without additional vitamin $\mathrm{E}$ and Selenium)

$\mathrm{T}_{1}$ (Control $+50 \mathrm{mg}$ vitamin $\mathrm{E}$ and $0.11 \mathrm{mg}$ selenium per $\mathrm{kg}$ diet)

$\mathrm{T}_{2}$ (Control $+100 \mathrm{mg}$ vitamin and $0.22 \mathrm{mg}$ Selenium per $\mathrm{kg}$ diet)

$\mathrm{T}_{3}$ (Control $+150 \mathrm{mg}$ vitamin $\mathrm{E}$ and $0.33 \mathrm{mg}$ Selenium per kg diet $)$

\subsection{Ration formulation}

The basal diets for broiler was formulated with the locally available feed ingredients. After weighing of feed ingredients, yellow corn, soybean meal, rice polish, and fish meal were hand mixed thoroughly. Then oyster shell and common salt were mixed properly with the whole feed. All the diets were divided equally and then vitamin E and Selenium premix were added according to experimental design. The mixed feed (diet) were 
stored in separated gunny bags. Broiler rations containing $22.2 \%$ Crude protein and $3150 \mathrm{kcal} / \mathrm{kg}$ metabolizable energy $15.36 \mathrm{mg} / \mathrm{kg}$ vitamin E, $0.36 \mathrm{mg} / \mathrm{kg}$ selenium.

\subsection{Preparation of house}

Twelve cages were considered for this trial and each having floor space of $0.91 \mathrm{~m}^{2}(120 \mathrm{~cm} \times 76 \mathrm{~cm})$. The experimental house and cages were properly cleaned and washed by forced water using a hose-pipe and then disinfected by bleaching powder. At the same time, all feeders, plastic buckets waterers and other necessary equipment's were cleaned properly, washed and disinfected with phenyl solution and subsequently dried and left empty for a week before the arrival of chicks. Wall and wire nets were thoroughly disinfected by spraying Vircons-S solution (Ante International Limited, England) in water and kept free to dry up properly.

\subsubsection{Litter management}

Fresh dried rice husk was spread on the floor under the cages at a depth of $4 \mathrm{~cm}$. After 3 weeks of age, upper layer of the litter with droppings were removed and replaced by new litter material. Every week's litter was stirred to prevent accumulation of ammonia gas and maggot formation.

\subsubsection{Light, temperature and ventilation}

For the control of temperature and light a 100-watt electric bulb was used for each cage. Electric light was provided in the trial house for 24 hours and the brooding temperature was maintained near about $34^{\circ} \mathrm{C}$ for first week and decreased gradually at the rate of $3^{\circ} \mathrm{C}$ in each week.

\subsubsection{Feeder and waterer management}

For the first 7 days, feeds were given on paper and water was supplied in a round waterer. One feeder and one waterer were provided for each cage (9 broilers). The feeders were thoroughly washed and cleaned at the end of each week and waterer was washed twice a day. Feeds and water were supplied ad libitum to all broilers.

\subsubsection{Biosecurity}

Proper bio-security measures were taken during the experimental period. Equipment's were made clean and disinfected. Footbath (containing solution of potassium permanganate) was maintained at the entrance of the experimental house.

\subsection{Vaccination}

The birds were vaccinated against Newcastle Disease at day 4 and day 20 and against Infectious Bursal Disease (Gumboro) at day 11. The vaccines werw collected from District Veterinary Hospital, Aqua, Mymensingh.

\subsection{Record keeping and collection of data}

The following parameters were recorded during the experimental period:

\subsubsection{Live weight and body weight gain}

Broilers were weighted in a group at the beginning of the trial and then every week at the age of day $7,14,21$, 28 and 35. Weighing was done using electric balance before supplying feed at morning of each week. The average body weight gain of broilers in each replication was calculated by deducting initial body weight from final body weight.

\subsubsection{Feed consumption and feed conversion efficiency}

Feed offered were recorded when supplied in cages and refusal at the end of each week also recorded. Feed intake and feed conversion efficiency were calculated by following formula:

$$
\text { (a) Feed intake per week }(\mathrm{g} / \mathrm{bird})=\frac{\text { Feed consumed in a week }(\mathrm{g})}{\text { Number of birds }}
$$

(b) Feed conversion ratio $(\mathrm{FCR})=\frac{\text { Feed intake }(\mathrm{g})}{\text { Weight gain }(\mathrm{g})}$

\subsubsection{Mortality}

Due to the fact that there is no death of bird occur during the experiment period. So there is no data was recorded for dead bird. 
2.8. Methods of broiler processing

At the end of the experiment, two broilers from each replication were randomly selected and slaughtered by a sharp knife. Then the chicks were scalded in hot water $\left(55-65^{\circ} \mathrm{C}\right)$ for about 3 minutes in order to loosen the feather of the carcasses. Final processing was performed by removal of the head, shank, viscera and lungs of the carcass. Heart and liver was removed from the remaining viscera by cutting them loose and then the gallbladder was removed from liver. The gizzard was removed by cutting it loose in front of the proventiculus and then cutting with both out going incoming and outgoing tracts.

\subsection{Dressing yield}

During processing several were recorded for live weight, blood loss weight, feather loss weight, dressing percentage, visceral weight, abdominal fat weight, giblet weight, breast meat weight, drumstick meat weight and thigh meat weight.

Dressing yield was calculated by subtracting blood, feather, digestive tract and shank from the live weight but gizzard, liver, abdominal fat head and neck were included with total processing meat. Dressing percentage was calculated by using the following formula:

Dressing percentage $=\underline{\text { Weight of dressed meat }(\mathrm{g}) * 100}$

$$
\text { Weight of live bird }(\mathrm{g})
$$

\subsection{Cost and income of broiler production}

The cost of broiler production for each treatment group was calculated based on the market price of feed ingredients, cost of chicks, management cost (Labour, medicine, electricity, litter, and depreciation etc.) to produce per kilogram of live broiler. The income from per kilogram live broiler in different treatment groups was calculated by the selling price of per kilogram live broiler. The net profit was calculated by deducting the cost of production per kilogram live broiler from selling price per kilogram live broiler.

\subsection{Statistical analysis}

Experimental data were analyzed for different variables accordance with the principle and procedures of Completely Randomize Design (CRD) and difference among the treatment means were determined by the least significant difference (LSD) method.

\section{Results and Discussion}

\subsubsection{Live weight $(\mathrm{g} / \mathrm{bird})$ in different weeks of birds}

Weekly live weight of broilers are presented in Table 1 where it shows that the initial average live weight ( $g / b i r d$ ) of the chicks was 103.85, 103.70,103.96 and 104.56 in treatment groups $\mathrm{T}_{0}, \mathrm{~T}_{1}, \mathrm{~T}_{2}$ and $\mathrm{T}_{3}$ respectively. The final average live weight (g/bird) of the birds were 1237.28, 1231.85, 1272.59 and 1218.85 in treatment groups $\mathrm{T}_{0}, \mathrm{~T}_{1}, \mathrm{~T}_{2}$ and $\mathrm{T}_{3}$ respectively. The result indicates that, for body weight there was no significant ( $>0.05$ ) differences at $2^{\text {nd }}$ and $3^{\text {rd }}$ weeks aged birds among the groups. But there was significant $(p<0.05)$ body weight differences in $4^{\text {th }}$, 5th and $6^{\text {th }}$ weeks aged birds and all the cases $\mathrm{T}_{2}$ group performing better.

Kennedy et al. (1992) found that the improvement of broilers growth may possible by feeding vitamin E. In another report, decreased growth rate was observed when lohman type broiler chicks were fed graded dose of vitamin E $(37.5,50$ or $100 \mathrm{ppm})$ with the diet (Ayed et al., 1988)

Table 1. Live weight (g/bird) in different weeks of birds.

\begin{tabular}{|c|c|c|c|c|c|c|}
\hline \multirow[t]{2}{*}{ Age (Week) } & \multicolumn{4}{|c|}{ Treatments } & \multirow[t]{2}{*}{ SE } & \multirow{2}{*}{$\begin{array}{l}\text { Level } \\
\text { of significance }\end{array}$} \\
\hline & $\mathbf{T}_{0}$ & $\mathbf{T}_{1}$ & $\mathbf{T}_{2}$ & $\mathbf{T}_{3}$ & & \\
\hline $2^{\text {nd }}$ & 103.85 & 103.70 & 103.96 & 104.55 & 9.84 & NS \\
\hline $3^{\text {rd }}$ & 243.47 & 262.21 & 266.66 & 252.58 & 15.27 & NS \\
\hline $4^{\text {th }}$ & $472.36^{b}$ & $479.15^{b}$ & $511.48^{\mathrm{a}}$ & $462.95^{b}$ & 18.08 & $* *$ \\
\hline $5^{\text {th }}$ & $757.54^{b}$ & $770.35^{b}$ & $802.21^{\mathrm{a}}$ & $753.31^{\mathrm{b}}$ & 21.90 & $* *$ \\
\hline $6^{\text {th }}$ & $1238.28^{b}$ & $1231.85^{b}$ & $1272.59^{a}$ & $1218.33^{b}$ & 24.51 & $* *$ \\
\hline
\end{tabular}

$\mathrm{T}_{0}$ (Control i.e without additional vitamin $\mathrm{E}$ and Selenium)

$\mathrm{T}_{1}$ (Control $+50 \mathrm{mg}$ vitamin $\mathrm{E}$ and $0.11 \mathrm{mg}$ selenium per $\mathrm{kg}$ diet)

$\mathrm{T}_{2}$ (Control $+100 \mathrm{mg}$ vitamin and $0.22 \mathrm{mg}$ Selenium per $\mathrm{kg}$ diet)

$\mathrm{T}_{3}$ (Control $+150 \mathrm{mg}$ vitamin $\mathrm{E}$ and $0.33 \mathrm{mg}$ Selenium per $\mathrm{kg}$ diet)

$\mathrm{NS}=$ Non-significant, $*=\mathrm{p}<0.05, \mathrm{SE}=$ Standard Error 


\subsubsection{Live weight gain}

The weekly live weight gain $(\mathrm{g} / \mathrm{bird})$ of broilers are presented in Table 2 where it shows that there was no significant difference ( $>00.05)$ among the groups in respect of weekly live weight gain. However, numerical highest weekly live weight gain (480.74 g/bird) was noted in birds fed ration under the treatment of $\mathrm{T}_{0}$ (control) followed by $\mathrm{T}_{2}$ (control $+100 \mathrm{mg}$ vitamin $\mathrm{E}$ and $0.22 \mathrm{mg}$ Selenium per $\mathrm{kg}$ diet), $\mathrm{T}_{3}$ (control $+150 \mathrm{mg}$ vitamin $\mathrm{E}$ and $0.33 \mathrm{mg}$ Selenium per $\mathrm{kg}$ diet) and $\mathrm{T}_{1}$ (control+50 $\mathrm{mg}$ vitamin $\mathrm{E}$ and $0.11 \mathrm{mg}$ Selenium per $\mathrm{kg}$ diet) respectively.

The better weight gain in the treated group of $\mathrm{T}_{2}$ (control+100 $\mathrm{mg}$ vitamin $\mathrm{E}$ and $0.22 \mathrm{mg}$ Selenium per $\mathrm{kg}$ diet) could be attributed to better digestion and assimilation of dietary nutrients brought about by the presence of 100 $\mathrm{mg}$ vitamin $\mathrm{E}$ and $0.22 \mathrm{mg}$ Selenium per $\mathrm{kg}$ diet in the present experiment. The present findings could be supported with the findings of Yuming et al. (2000), Yang hang et al. (2000) and Kokosharow et al. (1987) who reported the non-significant ( $p>0.05)$ difference in weight gain between birds fed different levels of vitamin $\mathrm{E}$ and Selenium.

Table 2. Effect of supplementation of vitamin $E$ and Selenium on weekly weight gain (g/birds).

\begin{tabular}{|c|c|c|c|c|c|c|}
\hline \multirow[t]{2}{*}{ Age (Week) } & \multirow[b]{2}{*}{$T_{0}$} & \multicolumn{2}{|c|}{ Treatments } & \multirow[b]{2}{*}{$T_{3}$} & \multirow[t]{2}{*}{ SE } & \multirow{2}{*}{$\begin{array}{l}\text { Level } \\
\text { of significance }\end{array}$} \\
\hline & & $T_{1}$ & $\mathbf{T}_{2}$ & & & \\
\hline $2^{\text {nd }}$ & 139.62 & 158.51 & 162.70 & 148.03 & 13.51 & NS \\
\hline $3^{\text {rd }}$ & 228.89 & 216.94 & 244.82 & 210.37 & 15.27 & NS \\
\hline $4^{\text {th }}$ & 285.18 & 291.20 & 290.73 & 290.36 & 21.90 & $\mathrm{Ns}$ \\
\hline $5^{\text {th }}$ & 480.74 & 461.48 & 470.07 & 465.52 & 40.81 & NS \\
\hline
\end{tabular}

$\mathrm{T}_{0}$ (Control i.e without additional vitamin $\mathrm{E}$ and Selenium)

$\mathrm{T}_{1}$ (Control $+50 \mathrm{mg}$ vitamin $\mathrm{E}$ and $0.11 \mathrm{mg}$ selenium per $\mathrm{kg}$ diet)

$\mathrm{T}_{2}$ (Control $+100 \mathrm{mg}$ vitamin and $0.22 \mathrm{mg}$ Selenium per $\mathrm{kg}$ diet)

$\mathrm{T}_{3}$ (Control $+150 \mathrm{mg}$ vitamin $\mathrm{E}$ and $0.33 \mathrm{mg}$ Selenium per $\mathrm{kg}$ diet)

$\mathrm{NS}=$ Non-significant, $*=\mathrm{p}<0.05, \mathrm{SE}=$ Standard Error

\subsubsection{Feed consumption}

Average daily feed consumption (g/bird) and the total feed consumption (g/bird) throughout the experimental period are shown in Table 3.The average daily feed consumption (g/bird) was 68.89, 70.10, 71.23 and 70.98 fed on ration under the treatment of $\mathrm{T}_{0}$ (control), $\mathrm{T}_{1}$ (control+50 $\mathrm{mg}$ vitamin $\mathrm{E}$ and $0.11 \mathrm{mg}$ Selenium per $\mathrm{kg}$ diet), $\mathrm{T}_{2}$ (control+100mg vitamin $\mathrm{E}$ and $0.22 \mathrm{mg}$ Selenium per $\mathrm{kg}$ diet) and $\mathrm{T}_{3}$ (control+150 $\mathrm{mg}$ vitamin $\mathrm{E}$ and 0.33 $\mathrm{mg}$ Selenium per $\mathrm{kg}$ diet) respectively. The results showed that the feed consumption by broilers was not influenced by supplemental vitamin E and Selenium from "Lolyvit-ES" because the weekly feed intake of all dietary treatment groups were found to be non-significant $(\mathrm{p}>0.05)$ in $2^{\text {nd }}, 3^{\text {rd }}, 4^{\text {th }}$ and $5^{\text {th }}$ week of the experimental period but it was found to be apparently higher for $T_{2}$ than other treatments $T_{0}, T_{1}$ and $T_{3}$. These results are in agreement with those of Yuming et al. (2000) who suggested that supplementation of vitamin $\mathrm{E}$ and Selenium did not influence feed consumption and tended to improve growth and feed utilization. Bhat and Ganai (1999) observed non-significant $((\mathrm{p}>0.05)$ difference in feed intake broiler diets supplemented with different levels of vitamin E. Similarly, Arrieta (2000) found non-significant ( $p>0.05)$ difference in feed intake among the treatment groups when fed different combinations of supplemental vitamin $\mathrm{E}$ and Selenium in the diet.

Table 3. Effect of vitamin $E$ and Selenium on weekly feed consumption (g/ bird).

\begin{tabular}{lllllll}
\hline \multirow{2}{*}{ Age (Week) } & \multicolumn{4}{c}{ Treatments } & SE & \multicolumn{2}{c}{$\begin{array}{l}\text { Level } \\
\text { of significance }\end{array}$} \\
\cline { 2 - 5 } & $\mathbf{T}_{\mathbf{0}}$ & $\mathbf{T}_{\mathbf{1}}$ & $\mathbf{T}_{\mathbf{2}}$ & $\mathbf{T}_{\mathbf{3}}$ & & $\mathrm{NS}$ \\
$2^{\text {nd }}$ & 299.22 & 306.82 & 309.79 & 345.15 & 24.87 & $\mathrm{NS}$ \\
$3^{\text {rd }}$ & 464.41 & 575.07 & 476.07 & 480.15 & 24.50 & $\mathrm{Ns}$ \\
$4^{\text {th }}$ & 678.48 & 701.87 & 703.37 & 709.60 & 34.03 & $\mathrm{NS}$ \\
$5^{\text {th }}$ & 1338.19 & 1040.04 & 1075.33 & 1020.19 & 60.19 & \\
\hline
\end{tabular}

$\mathrm{T}_{0}$ (Control i.e without additional vitamin $\mathrm{E}$ and Selenium)

$\mathrm{T}_{1}$ (Control $+50 \mathrm{mg}$ vitamin $\mathrm{E}$ and $0.11 \mathrm{mg}$ selenium per $\mathrm{kg}$ diet $)$

$\mathrm{T}_{2}$ (Control $+100 \mathrm{mg}$ vitamin and $0.22 \mathrm{mg}$ Selenium per $\mathrm{kg}$ diet)

$\mathrm{T}_{3}$ (Control $+150 \mathrm{mg}$ vitamin $\mathrm{E}$ and $0.33 \mathrm{mg}$ Selenium per $\mathrm{kg}$ diet)

$\mathrm{NS}=$ Non-significant, $*=\mathrm{p}<0.05, \mathrm{SE}=$ Standard Error 


\subsubsection{Feed conversion ratio (FCR)}

The feed conversion ratio (FCR) of broilers receiving different dietary treatments is shown in Table 4 . The feed conversion ratio $(F C R)$ were not significant $(p>0.05)$ at $4^{\text {th }}$ and $5^{\text {th }}$ week but at $1^{\text {st }}$ and $2^{\text {nd }}$ week they were significantly different $(\mathrm{p}<0.05)$ among them. The findings of the present experiment are in agreement with those of Yuming et al, (2000) and Bhat and Ganai, (1999) who observed no significant affects at supplementation of vitamin $\mathrm{E}$ at different levels.

Table 4. Effect of supplementation of vitamin $E$ and Selenium on weekly FCR.

\begin{tabular}{|c|c|c|c|c|c|c|}
\hline \multirow[t]{2}{*}{ Age (Week) } & \multicolumn{4}{|c|}{ Treatments } & \multirow[t]{2}{*}{ SE } & \multirow{2}{*}{$\begin{array}{l}\text { Level of } \\
\text { significance }\end{array}$} \\
\hline & $\mathbf{T}_{\mathbf{0}}$ & $\mathbf{T}_{1}$ & $T_{2}$ & $\mathbf{T}_{3}$ & & \\
\hline $2^{\text {nd }}$ & $2.14^{b}$ & $1.93^{\mathrm{b}}$ & $1.78^{b}$ & $2.32^{\mathrm{a}}$ & 0.10 & $*$ \\
\hline $3^{\mathrm{rd}}$ & $2.03^{\mathrm{b}}$ & $2.19^{\mathrm{b}}$ & $1.94^{\mathrm{a}}$ & $2.28^{\mathrm{b}}$ & 0.12 & $*$ \\
\hline $4^{\text {th }}$ & 2.37 & 2.42 & 2.41 & 2.64 & 0.11 & Ns \\
\hline $5^{\text {th }}$ & 2.16 & 2.25 & 2.15 & 2.29 & 0.30 & NS \\
\hline
\end{tabular}

$\mathrm{T}_{0}$ (Control i.e without additional vitamin $\mathrm{E}$ and Selenium)

$\mathrm{T}_{1}$ (Control $+50 \mathrm{mg}$ vitamin $\mathrm{E}$ and $0.11 \mathrm{mg}$ selenium per $\mathrm{kg}$ diet)

$\mathrm{T}_{2}$ (Control $+100 \mathrm{mg}$ vitamin and $0.22 \mathrm{mg}$ Selenium per $\mathrm{kg}$ diet)

$\mathrm{T}_{3}$ (Control $+150 \mathrm{mg}$ vitamin $\mathrm{E}$ and $0.33 \mathrm{mg}$ Selenium per $\mathrm{kg}$ diet)

$\mathrm{NS}=$ Non-significant, $*=\mathrm{p}<0.05, \mathrm{SE}=$ Standard Error

\subsection{Meat yield characteristics/dressing percentage}

The result on body weight, blood, visera, liver, heart, gizzard, shank, drumstick, breast, head and dressed weight (g/ broiler) are given in Table 5. The results indicate that dressed weight, shank and breast weight were significantly $(p<0.05)$ different among treatment groups. Shank weight was highly significant $(p<0.01)$ in $T_{2}$ from but there was no different among $T_{0}, T_{1}$ and $T_{3}$. Breast weight was highly significant $(p<0.01)$ in $T_{2}$ from $\mathrm{T}_{0}, \mathrm{~T}_{1}$ and $\mathrm{T}_{3}$ but there was no difference among $\mathrm{T}_{0}, \mathrm{~T}_{1}$ and $\mathrm{T}_{3}$.

In case of dressed weight there was significant different $(\mathrm{p}<0.01)$ in $\mathrm{T}_{2}$ from $\mathrm{T}_{0}, \mathrm{~T}_{1}$ and $\mathrm{T}_{3}$ but there was no different among $\mathrm{T}_{0}, \mathrm{~T}_{1}$ and $\mathrm{T}_{3}$. The similar findings were observed by Swain et al. (2000) who showed that there is positive significant effect of supplementation of vitamin $\mathrm{E}$ and Selenium on relative weight of some organs.

Table 5. Effect of supplementation of vitamin $\mathbf{E}$ and Selenium on different body parts and dressing \%.

\begin{tabular}{|c|c|c|c|c|c|c|}
\hline \multirow[t]{2}{*}{ Parameter } & \multicolumn{4}{|c|}{ Treatments } & \multirow[t]{2}{*}{ SE } & \multirow{2}{*}{$\begin{array}{l}\text { Level of } \\
\text { significance }\end{array}$} \\
\hline & $\mathbf{T}_{0}$ & $\mathbf{T}_{1}$ & $\mathbf{T}_{2}$ & $\mathbf{T}_{3}$ & & \\
\hline Live weight & 1091 & 1135 & 1186 & 1190 & 62.27 & NS \\
\hline Blood weight & 34 & 35 & 37 & 36.50 & 5.98 & NS \\
\hline Feather weight & 52 & 57 & 65 & 66 & 7.26 & Ns \\
\hline Viscera weight & 217.50 & 222 & 262 & 214 & 29.28 & NS \\
\hline Liver weight & 45 & 42.50 & 55 & 42 & 5.30 & NS \\
\hline Heart weight & 9.50 & 10 & 12.50 & 10 & 1.27 & NS \\
\hline Gizzard weight & 30 & 27.50 & 40 & 33.50 & 6.96 & NS \\
\hline Shank weight & $25^{\mathrm{b}}$ & $28.50^{\mathrm{b}}$ & $33^{\mathrm{a}}$ & $25^{\mathrm{b}}$ & 3.33 & $*$ \\
\hline Drumstick weight & 45 & 50 & 57 & 55 & 8.50 & NS \\
\hline Thigh weight & 56.50 & 57.50 & 65 & 70 & 7.96 & NS \\
\hline Breast weight & $128.33^{b}$ & $132.50^{\mathrm{b}}$ & $155^{\mathrm{a}}$ & $142.5^{\mathrm{b}}$ & 15.38 & $*$ \\
\hline Head weight & 36.83 & 45 & 48 & 45 & 5.47 & NS \\
\hline Dressed weight & $594.66^{\mathrm{b}}$ & $654.26^{\mathrm{a}}$ & $671.86^{\mathrm{a}}$ & $668.96^{\mathrm{a}}$ & 17.86 & $*$ \\
\hline dressing \% & 54.50 & 57.60 & 56.60 & 56.20 & 2.30 & NS \\
\hline
\end{tabular}

$\mathrm{T}_{0}$ (Control i.e without additional vitamin $\mathrm{E}$ and Selenium)

$\mathrm{T}_{1}$ (Control + $50 \mathrm{mg}$ vitamin $\mathrm{E}$ and $0.11 \mathrm{mg}$ selenium per $\mathrm{kg}$ diet)

$\mathrm{T}_{2}$ (Control $+100 \mathrm{mg}$ vitamin and $0.22 \mathrm{mg}$ Selenium per $\mathrm{kg}$ diet)

$\mathrm{T}_{3}$ (Control $+150 \mathrm{mg}$ vitamin $\mathrm{E}$ and $0.33 \mathrm{mg}$ Selenium per $\mathrm{kg}$ diet)

$\mathrm{NS}=$ Non-significant, $*=\mathrm{p}<0.05, \mathrm{SE}=$ Standard Error 
3.3. Economy of broiler production

The economic analysis of broilers on different treatment groups also is presented in Table 6. From the table, it can be seen that there were no significant $(\mathrm{p}<0.05)$ difference were observed for feed cost, total cost and net profit. In case of net profit there were no significant $(\mathrm{p}<0.05)$ differences among treatment groups $\mathrm{T}_{0}$ (control), $\mathrm{T}_{1}$ (control+50 $\mathrm{mg}$ vitamin $\mathrm{E}$ and $0.11 \mathrm{mg}$ Selenium per $\mathrm{kg}$ diet), $\mathrm{T}_{2}$ (control+100mg vitamin $\mathrm{E}$ and $0.22 \mathrm{mg}$ Selenium per $\mathrm{kg}$ diet) and $\mathrm{T}_{3}$ (control+150 $\mathrm{mg}$ vitamin $\mathrm{E}$ and $0.33 \mathrm{mg}$ Selenium per $\mathrm{kg}$ diet). The numerically higher value of the net profit (Tk./bird) 117.80 found in $T_{2}$ (control+100mg vitamin $E$ and $0.22 \mathrm{mg}$ Selenium per kg diet) due to the higher live weight gain. These results are in agreement with that of Sirbu et al. (1980), they reported that high dose of vitamin $\mathrm{E}$ increase thyroid activity as a result feed consumption is lower.

Table 6. Production cost and profit of chicks on different treatments.

\begin{tabular}{|c|c|c|c|c|c|c|}
\hline \multirow[t]{2}{*}{ Parameter (Tk./ bird) } & \multicolumn{4}{|c|}{ Treatments } & \multirow[t]{2}{*}{ SE } & \multirow{2}{*}{$\begin{array}{l}\text { Level of } \\
\text { significance }\end{array}$} \\
\hline & $\mathbf{T}_{\mathbf{0}}$ & $\mathbf{T}_{1}$ & $\mathbf{T}_{2}$ & $\mathbf{T}_{3}$ & & \\
\hline Chick cost & 17 & 17 & 17 & 17 & - & - \\
\hline Feed cost & 32.24 & 32.80 & 33.3 & 33.22 & 1.61 & NS \\
\hline Supplement & 0 & 1.38 & 2.76 & 4.14 & - & - \\
\hline Other cost & 5.46 & 5.46 & 5.46 & 5.46 & - & - \\
\hline Total cost & 54.70 & 56.64 & 58.5 & 59.89 & 1.51 & NS \\
\hline Sale income & 72.31 & 73.91 & 76.35 & 73.13 & 2.17 & NS \\
\hline Net profit & 17.61 & 17.27 & 17.80 & 13.24 & 2.26 & NS \\
\hline
\end{tabular}

$\mathrm{T}_{0}$ (Control i.e without additional vitamin $\mathrm{E}$ and Selenium)

$\mathrm{T}_{1}$ (Control $+50 \mathrm{mg}$ vitamin $\mathrm{E}$ and $0.11 \mathrm{mg}$ selenium per $\mathrm{kg}$ diet)

$\mathrm{T}_{2}$ (Control $+100 \mathrm{mg}$ vitamin and $0.22 \mathrm{mg}$ Selenium per $\mathrm{kg}$ diet)

$\mathrm{T}_{3}$ (Control $+150 \mathrm{mg}$ vitamin $\mathrm{E}$ and $0.33 \mathrm{mg}$ Selenium per $\mathrm{kg}$ diet)

$\mathrm{NS}=$ Non-significant, $*=\mathrm{p}<0.05, \mathrm{SE}=$ Standard Error

In the experiment, it was observed that there were no significant $(\mathrm{p}<0.05)$ differences in live weight gain, feed consumption, feed conversion ratio, meat yield characteristics and net profit of chicks fed different level of supplemental vitamin E and Selenium in broiler rations. Although the numerical vitamin improvement of live weight gain and feed conversion ratio of the treatment group $\mathrm{T}_{1}$ was observed. Many researchers have reported that the combination of higher level of vitamin E and Selenium in the diets of broiler could be beneficial for their cellular and hormonal immune response (Swain et al., 2000 and Whitacre et al., 1987). The supplementation of $100 \mathrm{mg}$ vitamin E and $0.22 \mathrm{mg}$ Selenium from "LoLyvit-ES" may have some positive impact on cellular and hormonal immune response under Bangladesh condition.

\section{Conclusions}

Based on the above findings, the result suggested that supplementation of Vitamin E $100 \mathrm{mg}$ and $0.22 \mathrm{mg}$ Selenium per kg diet from "Lolyvit-ES" as a source of Vitamin E and Selenium may be used in broiler rations.

\section{Acknowledgements}

The author would like to give thanks to Department of Animal Nutrition, Bangladesh Agricultural University, Mymensingh-2202, Bangladesh.

\section{Conflict of interest}

None to declare.

\section{References}

Ahmad S and Islam N, 1990. Backyard Poultry Development Project in 100 village. Proceeding of the $1^{\text {st }}$ conference of Bangladesh Animal Husbandry Association. 23-24 February 1985, BARC, Dhaka, Bangladesh. pp.133-138.

Arrieta JM, CA Diaz, E Avila-gonzalez, R Guinzberg-perrus and E Pina-Garza, 2000. Oxidative hepatic status and productive behavior of broilers, fed on two sources of selenium and high levels of vitamin $\mathrm{E}$ and $\mathrm{C}$. Veterinaria-Mexico, 31: 113-119.

Ayed LA, R Dafall and S Adam, 1988. Effects of various levels of dietary vitamin E on broiler chicks. Veterinary Human Toxicology, 31: 50-53. 
Badwey JA and ML Karnovsky, 1980. Active oxygen species and the function of pathogenic leukocytes. Annu. Rev. Biochem., 49: 695.

Bhat, GA, SA Wani and TAS Ganai, 1999. Effects of feeding vitamin E on the performance of broilers under temperate agro-climate condition. Indian J. Poult. Sci., 34: 83-85.

Combs GFJ and ML Scott, 1977. Nutritional interrelationships of vitamin E and selenium. BioScience, 27: 467473.

Kakosharov T, D Orlova and G Ivanov, 1987. The effects of selenium on the growth rate of broiler chicks. Veterinarna-Sbirka, 85: 15-16.

Kennedy DG, DA Rice, DW Bruce, EA Goodall and SG Mellory, 1992. The economic effects of increased vitamin E supplementation of broiler diets on the commercial broiler production. Brit. Poult. Sci., 33: 10151023.

Lessard M, WC Yang, GC Elliott, AH Rebar, JF VanVleet, N Deslauriers, GJ Brission, RD Schultz, 1991. Cellular immune responses in pigs fed a vitamin E- and selenium deficient diet. Janim Sci. 69:1575-1582.

McDowell LR, SN Williams, N Hidiroglou, CA Njeru, GM Hill, L Ochoa and NS Wilkinson, 1996. Vitamin E supplementation for the ruminant. Animal Feed Sci. and Tech., 60: 273-296.

National Research Council, 1983. Nutrient requirements of domestic animals, Nutrient requirements of warm water fisges and shell fishes. $2^{\text {nd }}$ edition. National Academy of Science. National Research Council, Washington DC.

National Research Council, 1994. Nutrient requirements for poultry. $9^{\text {th }}$ edition. National Academy Press Washington DC.

Sheffy BE and AJ Williams, 1981. Vitamin E in health and diseases. Nutr. Abstr. Rev. (Series B), 54: 5519.

Sirbu M, D Tureu, and E Rotunheanu,1981. Effects of dietary vitamin E on feed intake and growth of meat and egg strain chicks. Nurt. Abstr. Rev. (Series B), 53:4370.

Swain BK and TS Johri, 2000. Effect of supplementation of combinations of different levels of selenium and vitamin E on relative weight of some organs and serum enzyme level in broiler. Ind. J. Poultry Sci., 35: 6669.

Ullery DE, 1974. Trace Element Metabolism in Animal (TEMA-2). pp.275.

Yuming G, T Qing, Y Jianmin and J Zhirongh, 2000. Supplemental effect of vitamin E on poultry performance. Animal Feed Sci. and Tech., 89: 165-173. 